\title{
Social Media and Group Consciousness in Nigeria: Appraising the Prevalence of Socio-Political Protests
}

\author{
Amobi P. Chiamogu1, 0. S. A. Obikeze'2, Uchechukwu P. Chiamogu1, Emeka Odikpo² \\ ${ }^{1}$ Department of Public Administration, Federal Polytechnic, Oko, Nigeria \\ ${ }^{2}$ Department of Political Science, Chukwuemeka Odumegwu Ojukwu University, Igbariam Campus, Nigeria \\ Email: amobi.chiamogu@federalpolyoko.edu.ng, os.obikeze@coou.edu.ng, uchep.chiamogu@federalpolyoko.edu.ng, \\ edemeka2014@gmail.com
}

How to cite this paper: Chiamogu, A. P., Obikeze, O. S. A., Chiamogu, U. P., \& Odikpo, E. (2021). Social Media and Group Consciousness in Nigeria: Appraising the Prevalence of Socio-Political Protests. Open Journal of Political Science, 11, 682-696. https://doi.org/10.4236/ojps.2021.114043

Received: August 22, 2021

Accepted: October 19, 2021

Published: October 22, 2021

Copyright $\odot 2021$ by author(s) and Scientific Research Publishing Inc. This work is licensed under the Creative Commons Attribution International License (CC BY 4.0).

http://creativecommons.org/licenses/by/4.0/

\begin{abstract}
Over time, internet penetration, social media production and consumption have skyrocketed with the unparalleled hike in advancement, adaptation and usage of information communication and technologies (ICTs). This geometric increment has greatly influenced the character of politics and administration in countries especially in emergent liberal democracies where populism has continued to be misapplied. In such countries, Nigeria inclusive, political leaderships have strangulated safeguards through mindful annihilation of institutions of checks and balances thereby subjugating the citizenry. Social media has thus turned out a veritable platform for activists to create awareness on socio-political issues and mobilize protests. This study, therefore, focuses on the strength of social media in creating social, political awareness and mobilizing political protests in Nigeria. In this study, the \#BringBackOurGirls, \#RevolutionNow and \#EndSars protests as test cases will be examined to understand the dynamic role of social media in creating group consciousness and mobilizing political protests in Nigeria. The study problematique will be approached using the qualitative research design through secondary sources of data that shall be analyzed content-wise. Based on the in-depth espouse of related literature, the social movement theory serves as the basic theoretical framework of analysis for the study. The study observed that a long period of marginalization and suppression of sections of the Nigerian society capped in lack of accountability and irresponsible governance constitute the major rationale for the massification of groups on social media. It also observed that orchestrated repressive measures bottled up anger in individual citizens who converge on social media groups to ventilate their displeasure and grievances. These social media platforms which enable seamless
\end{abstract}


and rapid distribution of socio-political information generate public sympathy that wakes up clannish ties, propels people, to sum up group grievances and incite members against the state. The study, therefore, surmised that widespread smartphone usage boosts group consciousness and facilitates group mobilization and protests against bad leadership.

\section{Keywords}

Social Movements, Democratic Populism, \#BringBackOurGirls, \#RevolutionNow, \#EndSars, Political Protests

\section{Introduction}

Unparalleled growth in social media penetration and usage is exponentially shaping (tele)communication patterns and networks across the globe. Social media platforms, such as Facebook, Youtube, Academia, Linkedin, MySpace, WeChat, Instagram, Twitter, WhatsApp, etc. have radically changed how information is shared and disseminated (Allcott \& Gentzkow, 2017). Information is seamlessly transmitted simultaneously in virality to users often without filtering and verification thereby making it harmful, damaging and destructive (Teh, Huah, \& Si, 2014). This way, the doings and ruinations of governments are disseminated in conspiracies and innuendoes to generate public sympathy, incite citizens especially members of suppressed, marginalized and disadvantaged ethnic/sectional groups. At that, citizens especially the most concerned begin to demand justice and accountability by coalescing on social media groups where their common injuries are opened up to hurt members even more in what the Nigerian government would refer to as hate speeches. Divisive information could indeed disrupt state affairs and national unity by damaging individual lives and group heritages (Torres, Gerhart \& Negahban, 2018). Nigerians share and disseminate news, information and knowledge in the forms of articles, comments, audio records, video clips to and within their social media circles. Where this information and knowledge have an overarching influence on readers/users' (group members') behaviour and perception of the state and the government, studies show that social media platforms are used for various purposes ranging from social networking, communication, interests aggregation and membership recruitment to socio-political mobilization, political/electioneering campaign to electoral participation, information dissemination to education, entertainment and product/brand marketing, etc. Posts, comments and representations on social media do also engage, create and reawaken group consciousness by sensitizing and painting common issues as collective problems that deserve group care and attention.

The nature of social relations that obtain between and among ethnic nationalities, sectional groupings and the Nigerian state create rancour, feeling of alienation, segregation, marginalization and domination. Lopsided allocation and dis- 
tribution of values (in forms of jobs, natural resources, public positions, admission into unity schools, etc.) in spite of the existence of federal character principle and other accommodative measures make the Nigerian state greatly disunited in diversities as a plural society. These unequal treatments generate advantaged and disadvantaged ethnoreligious and myriads of competing for suboptimal relations amongst groups in the Nigerian state. The level of injustices and unresponsive tendencies in the distribution of values (critical infrastructure, access to key public positions, etc.) meted out to disadvantaged groups conduce to deprivation and aggression when the narrative is circulated on social media. Hence, the resultant rivalries within and between groups and even against the state conduce to intractable conflicts or sheer lack of convergence in the wake of unprecedented internet and social media penetration and usage amongst citizens.

\subsection{Statement of the Research Problem}

Over time, the persistent violation and abuse of basic human rights, government insensitivities, neglect, ill-treatment of sections or groups, social injustice, acts of marginalization, political alienation, deprivation and domination have deeply polarized and created heightened inequalities amongst citizens, ethnoreligious and other sectional groups in Nigeria. It has been bottled anger and grievances against rival groups and the government on horizontal and vertical dimensions. With unregulated digitalization manifesting in widespread internet penetration and usage of social media platforms where ideas, images, and strategies circulate quickly and virally, many citizens now engage and confront the government and its agencies through social media activism. The entire citizenry or its parts and sections can now be mobilized against the injustice and insensibilities of the government without getting easily hounded. The hitherto limited media freedom has been busted in social media activism where negative narratives and damaging innuendoes against the government or groups are disseminated with spontaneous virality. More citizens are now aware and mobilized through these social media platforms leading to quickened group coalesce, mobilization and socio-political protests as seen with the \#BringBackOurGirls, \#RevolutionNow and \#EndSars movements in Nigeria.

\subsection{Study Objectives}

As such, this study aims at determining how clannish, sectional and group behaviours emerge and metamorphose into protests and movements from the use of social media. It also seeks the following specific goals:

1) To examine how social media is deployed in creating socio-political awareness and mobilizing political protests in Nigeria;

2) To analyze the \#BringBackOurGirls, \#RevolutionNow and \#EndSars Protests as test cases of how social media served as veritable tools for socio-political mobilization and awakening group consciousness that resulted in mass protests 
in Nigeria.

\section{Literature Review: Social Media and Group Consciousness in Context}

\subsection{Social Media}

In contemporary times, technology has changed the media landscape with geometric rise in internet and web-based media penetration. The more people imbibe the use of ICTs, devices and applications keep evolving and engaging them in an unprecedented manner. The evolution of internet-enabled androids, IOS and Windows devices have created unimaginable scope for digitalization in media technology. The emergent digital communication has given rise to interactive web applications describing a phenomenon commonly referred to as social media. Social media, therefore, is an interactive web-based application that enables users to network, socialize, interact (communicate), share and disseminate information, knowledge and market ideas and products at little or relatively no cost with one another (Baruah, 2012). The uniqueness of social media lies in its instantaneity, interactivity, virality, seamlessness and cost-effectiveness. Social media platforms or sites are web-based applications that accentuate interactions between users on end-to-end encryption. It involves participation and interoperability for end-users in sharing posts, comments, experiences, ideas in forms including audio and visual clips.

\subsection{Group Consciousness}

This is a superlative concept that describes a situation where members of a group (ethnic, racial, religious, political, sectional, etc.) sharing some unique ties come to learn and/or become aware of how their identities and related issues including their history, background and exploit of their perceived rivals/common enemies impact their members and or common interests and impinge their relationships with other groups. This situation causes group members to come together, coalesce and become ready to promote their shared values in rivalry and acrimonious relations with other groups and the state (Miller, Gurin, Gurin, \& Malanchuk, 1981). Group consciousness has two basic prerequisites of group membership and identification (Conover, 1988). Whereas group membership describes expression of sense of belongingness by members to the group, group identification explains the prejudiced emotional importance of the group to members. Intriguingly, by means such as belief system, religious practice, shared recitals, or demonstrations expressed in sync with other members, group consciousness generate collective emotions of the feeling of resentment that translate to nationalism and other feelings including commitment to promotion of common heritage in situation of injury or injustice. This lure and draw members to get involved in movements, demonstrations and protests believed to advance shared interests of group members. A stitch around the areas of shared interests by way of describing injury to members or the entire group instigate and incite 
collective action for the group which could come in the form of socio-political protests.

\subsection{Political Protest}

Political protest is a concept that refers to group action or attempt designed to bring about the stoppage of perceived injury and or injustice in a political system. It describes public expression of critical views, dissent, opposition, dissatisfaction with a policy or action of the government. Such actions especially peaceful ones are not primarily aimed at violently ousting the political leadership but calling their attention to change a situation that negatively affects a group, a section or the general public. Political protests are not revolutions; they are similar to political demonstrations of peaceful assembly that are allowed in democratic societies. Most times, people protest because they consider all other legitimate and traditional means of getting the government to address injuries and injustices meted out to them ineffective. Political protests assume violent and non-violent forms. Protests are said to be non-violent when they are conducted in forms of strike, sit-at-home, peaceful march/demonstration, open letters, press releases. On the other hand, violent protests are public demonstrations that involve destruction of property, inflicting bodily injuries and killings, vandalism of public assets. Non-violent political protesters usually obtain permit from law enforcement agents before embarking upon their activities and are normally powered by activists.

What is more, the use and membership of social media groups generate a sense of engagement or loyalty from members who by reading, watching and or listening to shared contents are incited and mobilized to rise against other groups or even the state. By sharing information and soliciting feedback on collaborative social media handles such as twitter, Facebook, WhatsApp, Instagram, Telegram, YouTube, etc., members of groups post resentful, damaging information, views and hateful ideas that are easily internalized, shared, commented upon in tones that heighten emotions that propel anger and animosity against other groups or the state. That way, hateful actions emanating from governance challenges giving to mass poverty, dysfunctional educational system, poor access to healthcare delivery, massive graduate unemployment, police brutality, deplorable state of public infrastructure, unbearable socio-economic and political conditions are disseminated and communicated to the people in negative narratives and damaging innuendoes using social media platforms to generate public sympathies that coalesce to mass actions. Hence, generate hateful speeches in resentful narratives that spur and incite group members to rise to confront the perpetrators or even change the status quo in demand for justice and fair share of values in the state.

\subsection{Review of Theoretical Underpinnings: The New Social Movement Theory}

Social Scientists seek to understand the causes, explain the how and determine 
the forms of social movements. What gives rise to social movements? Are the causes political or economic or cultural in nature? Scholars have generated and adduced various theories to describe the emergence, mobilization and citizens' participation in socio-political movements and protests (Phongpaichit, 1999). At the dawn of the $21^{\text {st }}$ century and vast advancements in ICTs which limit space by enabling spontaneous transmission of views that coagulate sentiments for public sympathy in manners that generate unassuming concerns for dissent, explanation of the birth, growth and maturation of social movements becomes wieldy. ICTs provide convenient opportunities for resurgent socio-political movements and protests at the wake of rising violation of human rights, declining democratic ethos especially muzzled media and executive ascendancy. Prominent amongst the variant theories advanced to explain the rising tide of social movements include: relative deprivation, resource mobilization, political process, structural strain, and new social movement theories. This study however, reviewed only the deprivation, political process and the new social movement theories.

\subsection{Deprivation Theory}

This theory which was first described by Robert Merton contends that some social movements emerge when a people or group(s) of people in a society feel deprived of a specific good, service, or resource (McAdam, McCarthy, \& Zald, 1988). The primary argument of this theory relies on resources/value allocation, social injustice, suppression and marginalization perception arising from comparison with other sections or groups in a society. Deprivation theory provides authoritative rationales for the emergence of social movements but fails to explain why some deprivations fail to generate social movements. Hence, the presumption that even when deprivation might result in social movement that all forms of deprivation do not always give rise to emergence of social movements. Invariably, deprivation theory does not wholly and always explain the rationale for the emergence, growth and mobilization of social movements.

\subsection{Political Process Theory}

This variant of the social movement theory treats all group protests and demonstrations as a type of political movement on the presumption that their origins are traceable to the availability of political opportunities. It sees all social movements from the angle of state and government relationships with the citizens regarding authoritative allocation of values. Few social movement theorists would have any problems with the political process theory emphasizing the importance of political conditions and attendant political opportunities (or lack thereof) in determining the chances of success for a nascent social movement. The primary criticism of this theory is that it focuses too much on political circumstances and ignores cultural factors that might be strong enough to mitigate the effect of the political factors and vice versa. 


\subsection{New Social Movement Theories}

The new social movement theories became popular in post 1960s Europe following observed inabilities of classical Marxist theories to explain group actions (Buechler, 1995). The new theories broadened emphasis from economic perspectives to political, ideological, cultural and primordial considerations. It brought such socio-political group motivators as ethnicity, nationality, gender, sexuality, etc. to the fore. At that, changes in politics and times began to reshape theoretical approaches to understanding contentious politics. The late 1960s witnessed unprecedented rise in civil rights, peace, students', women's, and other forms of demand for accountability movements thereby changing scholars' interpretations and perceptions of group actions from irrational outbursts to movement activities with definite objectives (van Stekelenburg \& Klandermans, 2009). New social movement theories operate in an ideological environment framed by issues relating to fundamental human rights vis-à-vis the state's rights over its citizens. Hence, with ICTs and globalization, times and politics have continued to change at unprecedented pace. Since the 1990s, the context of contentious politics has bourgeoned in inseparably intertwined with advancement processes of information and communication technologies (ICTs) generating massive global internet penetration and social media usage thereby birthing the age of new media. Social networks have become the engine and mode of communication to more diffuse group belongings (Norris, Walgrave, \& van Aelst, 2005). The dissemination of information and spread of networks constitute the basic features of social mobilization and as such forms a platform for socio-political contention that tends to normalize protests and demonstrations in the age of massive group awareness and consciousness.

In this context therefore, it is observed that several reasons existing in the social, political and economic spheres of life birth conduce to social movements. Invariably, the theories of relative deprivation, political process and the new social movement are all meaningful in holistic explanation of the possible causes, birth, growth and even resurgence of political protests. Whereas, deprivation theory sees it from the perceived feeling of deprivation, the political process theory holds that groups rise when they share the feeling that they have been sidetracked and are becoming irrelevant in authoritative allocation of values. The good value in the combination of these theories is that the limitations of the deprivation are covered by the process or the new social movement theories and vice versa. At that, we close all possible vents of laxity and shortfall in explaining the why and how of social movements in Nigeria.

The study therefore leveraged upon the tenets of these theories all of which are forms of social movement and adopted the New Social movement theory as its framework of analysis which explains the why, how and forms of social mobilization while describing their potential social, cultural, and political consequences in the age of digitalization. The theory among other things explains the rationale for the resurgence of group consciousness thereby describing why 
there is prevalence of socio-political protests.

\section{Methodology}

The study adopted qualitative research method that allowed the researchers latitude to evaluate incidences and circumstances leading to the creation of awareness and mobilization of citizens for socio-political protests and movement in Nigeria using social media platforms. It also provided explanations for why and how people joined and promoted the protestations by highlighting the extent of suppression of human rights especially those of freedom of expression and media with particular emphasize on \#BringBackOurGirls, \#RevolutionNow and \#EndSars protests. Consequently, data for the study is sourced from books, journal articles, newspapers and expert publications addressing issues of governance challenges, socio-political alienation, deprivation, violation of human rights, press freedom and orchestrated injustices and ill-treatment of disadvantaged sections and groups in the Nigerian state.

\subsection{Social Media Groups in Nigeria}

The advent of wide internet penetration and broadband coverage has revolutionized the use of smart phones and other android devices in Nigeria. According to Data Reportal (2021), the number of internet users in Nigeria increased by 19 million people (representing 22\% increment from 2020 statistics) to 104.4 million in January 2021 at a record internet penetration of 50.0\%. In January 2021, Nigeria recorded 187.9 million mobile connections which is equivalent to $90 \%$ of the total population. Equally, the number of social media users increased by 6 million (representing 22\% increment from 2020 statistics) to make 33 million in January 2021. The number of social media users in Nigeria was equivalent to $15.8 \%$ of the total population in January 2021. The distribution of these social media users on social media sites as can be seen on Table 1 below shows that whatsApp messenger is the most used platform at (93\%) followed by Facebook (86.2\%), Youtube (81.6), Instagram (73.1\%) and Twitter at $61.4 \%$.

Table 1. Most used social media platforms in Nigeria as of the $3^{\text {rd }}$ quarter of 2020.

\begin{tabular}{ccc}
\hline S/N & Social Media Site & $\%$ \\
\hline 1 & WhatsApp & 93 \\
2 & Facebook & 86.2 \\
3 & Youtube & 81.6 \\
4 & Instagram & 73.1 \\
5 & Facebook Messenger & 67.2 \\
6 & Twitter & 61.4 \\
7 & Telegram & 56.3 \\
8 & Linkedin & 32.8 \\
9 & Tik tok & 31.9 \\
\hline
\end{tabular}


Continued

\begin{tabular}{ccc}
\hline 10 & Snapchat & 31.2 \\
11 & Pinterest & 26.8 \\
12 & Skype & 12.1 \\
13 & Google Hangout & 11.6 \\
14 & Reddit & 9.1 \\
15 & WeChat & 5.7 \\
16 & Tumblr & 4.1 \\
\hline
\end{tabular}

Source: Varrella (2021). Leading social media platforms in Nigeria.

There are several social media chat groups where Nigerian subscribers socialize, interact, communicate and share ideas and information. Table 1 above shows that Nigerians use more of such social media platforms that have messengers where they easily get added or join group chats like WhatsApp and Facebook messengers. As such, there are several WhatsApp and Facebook chat groups ranging from States, Senatorial Districts, Federal Constituencies, State Constituencies, Local Government Areas, Clans, Town Union, Wards, Communities, Villages, Families, Party Groups, Professional Associations, Labour Unions, Alumni Chat Groups, Social Clubs, City chat groups, et cetera. Hence, there are Anambra State Groups, Anambra North Groups, Omambala Groups, Aguata Groups, Owerri Group Chat, Calabar Group Chat, Ibadan Group Chat, Job Seekers Group Chat, Sons and Daughters Group Chat of many communities, National Youth Service Corps (NYSC) state by state groups, Hackers groups, Comedy Groups, Money Making Groups, Educational Groups, Old Boys of Schools/Colleges Groups, Adult Groups, etc. Every sectional or clannish Nigerian interests including those you can never imagine exist on social media with astonishing membership. Most Nigerian social media users get added to groups without their permission. The need for contacts and connections coupled with the euphoria of gaining access to new technology and information push many to remain members of such groups. A few others select and decide groups to join. Many join groups or chat rooms for passion, compassion, in search of information, knowledge and crave for belongingness.

\subsection{Social Media and Group Consciousness in Nigeria}

In contemporary terms, social media activism is a type of shared pressure group involving the use of information and communication technologies (ICTs) applications and devices to communicate and share information, ideas, thoughts, and opinions about injuries, injustices, observed laxities in government that generate public outcry and bring awareness of the people or members of a group to certain issues and causes. Social media users share information, resentful actions and inactions of the government on social media sites with a much broader audience to instigate, propagate and incite social and political movements. Social media activism is breaking bridges by enabling more people to participate in it. 
From Twitter hashtag, Nigerian activists generated and attracted media and global attention to the causes of fight against Boko Haram via \#BringBackOurGirls, against bad leadership and lack of accountability in government via \#RevolutionNow, against police brutality and violation of human rights via \#EndSars protests.

\section{3. \#BringBackOurGirls Protests}

The \#BringBackOurGirls (BBOG) movement emerged in April 2014 under the administration of President Goodluck Ebele Jonathan as a result of the abduction of over 200 school girls from Government Secondary School, Chibok in Borno state, North Eastern part of Nigeria, by the Boko Haram Islamist insurgency group (Ojebode, 2018). It aims at pressurizing the government to confront Boko Haram and bring the abducted school girls back home safely. BBOG is thus a heated reaction of citizens who are tired of the killings of innocent and defenceless children in Nigeria. BBOG organized its initial public protest on April 30, 2014 at the famous Unity Fountain in Abuja from where participants and members agreed to stand with parents of the abductees until their children returned to them. With bourgeoning spate of insecurity in the Northeast, the aim and scope of the movement kept widening to include protests for the release of some women abducted in Bassa, some university of Maiduguri lecturers kidnapped from fieldwork. BBOG movement extended its scope from safety and security of citizens from Boko Haram insurgency ravaging the Northeast to demand for good governance in Nigeria.

The BBOG movement generated the convergence of online rage and the offline rallies in and outside Nigeria and elicited solidarity and support from all cadres of people and countries. Accordingly, social media played a pivotal role in ensuring that the Federal Government of Nigeria, which had hitherto denied the abduction, paid attention to the demand for rescue of the girls and the general security of its citizens. BBOG is one of Nigeria's intense social media driven and female-led actions with sustained viral online advocacy. The first live tweet of \#BringBackOurGirls, which said "bring back our daughters, came from Ibrahim Abdullahi during a televised speech by Oby Ezekwesili". The hashtag attracted great international attention from world leaders, media groups and celebrities. The BBOG metamorphosed from hashtag \#BringBackOurGirls to physical movement when its course was adequately sold and bought by people who have personal stakes. This was how the protest began in Nigeria, mothers whose children were taken used this hashtag to protest around the streets of Abuja. The sharing of the hashtag by over one million times on social media drew international attention to the activities of Boko Haram and the \#BringBackOurGirls Movement and protests in Nigeria.

\section{4. \#RevolutionNow Protests}

\#RevolutionNow is a socio-political movement organized by the Coalition for 
Revolution (CORE), a political movement of the Nigerian masses and youths, led by Omoyele Sowore, an activist and former presidential candidate of the African Action Congress (AAC). \#RevolutionNow according to Aye (2019) was a nation-wide protest march that commenced on August 5, 2019 to press home the following 5-core demands:

1) An economy that works for the masses: CORE rejects an economy that impoverishes 90 million citizens, while paltry 5 persons own N11 trillion;

2) Effective and democratic end to insecurity: rejects widespread poverty, discrimination, press repression and manipulation of ethnic differences by the political leadership;

3) End to political corruption: CORE rejects widespread systemic corruption and demands systemic change and building of a new society based on solidarity and democracy;

4) The immediate implementation of N30,000 minimum wage for Nigerian workers. CORE demands payment of all salary arrears and placement of politicians on civil service salary scale while demanding living wage for all from 2021;

5) Free quality and functional education for all. Education is a right and not a privilege. CORE demands massive investments to develop public schools' infrastructure and informed review of curricula to promote critical thinking and independent student unionism.

It garnered support and became widespread with a July 29, 2019 tweet from their leader on the hashtag \#RevolutionNow. The hashtag earned the coalition support of many Nigerians who are desirous of good governance. People joined the protests even against established police brutality and harassment. Sowore used the social media especially Twitter to draw the attention and waken the consciousness of Nigerians who are deprived of quality education, living wage, suffering from abject poverty, insecurity, mass abuse of human rights, economic disequilibrium, massive graduate unemployment among other debilitating socio-economic and political conditions. Members found common cause in the protest because it expressed their shared interests and provided platform for expressing their grievances. People joined the protests as it touched their psyche and participated massively because social media provided formidable platforms for their mobilization.

\section{5. \#EndSars Protest}

The \#EndSars protest started on October 8, 2020 as a result of a gory video clip that went viral on social media about Special Anti-Robbery Squad (SARS) officers shooting a young man in Ughelli, Delta State on October 3 and, fleeing with his Lexus SUV vehicle (Ugobude, 2020). The video generated massive outrage and made many Nigerian youths to share their various traumatic experiences with the hashtag \#EndSARS. The Special Anti-Robbery Squad (SARS) unit of the Nigerian Police Force was formed in 1992 to fight violent crimes. SARS officers operate in unconventional ways in fighting organized crime and armed robbers. There were recorded serial allegations of brutality, abuse of basic human rights, 
extortion, rape and extra-judicial killings against SARS operatives. The video clip and other gory tales of police brutality amplified the \#EndSars movement which began on Twitter in 2016 with many mobilizing for peaceful demonstration in cities around the country. Social media was the heart of the spread of the protests through the employment of hashtags including \#EndSARS, \#SarsMustEnd, \#EndSWAT, \#EndPoliceBrutality and a host of others to coordinate their activities, planning, and execution in the different cities in Nigeria, as well as abroad. These hashtags trended internationally and earned membership from celebrities, attention of media groups and human rights watch while serving as a bookmark for gruesome tales of surviving victims or their relatives (Ugobude, 2020). Many affected persons, relatives and families joined the hashtags and mobilized massively to sustain the physical protests across Nigerian cities. Within days, the use of social media for mobilization and group consciousness made \#EndSARS protest the most engaging youth-led movement ever organized in Nigeria.

SARS brutalized Nigerians especially the youths for years with countless gruesome experience but the use of social media occasioned public scrutiny of the unit and buried it. According to Sturken and Cartwright (2018: p. 15), social media has extensively enlarged social and political movements which are generated by violation and abuse of basic human rights, government insensitivities, neglect, ill-treatment of sections or groups, social injustice, acts of marginalization, political alienation and domination in a digital world where ideas, images, and strategies circulate quickly and virally. Digitalization fosters seamlessness and virality of information which quickens group coalesce, mobilization and participation in protests as seen with the \#BringBackOurGirls, \#RevolutionNow and \#EndSars movements in Nigeria. The use of the social media made these movements to reach wider range of people within and outside the country and mobilized greater number of protesters against the cause.

\subsection{Social Media and Prevalence of Socio-political Protests in Nigeria}

Realizing that social media is a coalescing platform that seamlessly and instantaneously reaches wider people, makes interests articulation and group mobilization soft works and wieldy in the digital age, activists and members of disadvantaged groups have resorted to the use of social media handles as a tool for creating group consciousness and mobilization against the government. There is a wide spectrum of social media users including activists and international agencies whose onus negates social injustices and human rights violations. All sorts of groups and organizations ranging from feminist, human rights, Amnesty International, pro-democracy advocacy groups, election observer groups, press freedom including those other chat groups that fuel activism abound on the social media. These groups take information, ideas, events and stories of human dignity and interests of members seriously. They market and demarket ideas through dissemination and disinformation to achieve their target goals. These sharing and transmission of ideas and events form and deform members as 
supporters, fans and members of causes to faults. These engaged and incited members act in the desired direction based on level of group consciousness and awareness of interests resulting in protests.

In Nigeria, the \#BringBackOurGirls, \#RevolutionNow and \#EndSars amongst other socio-political movements/protests were amplified using such highly subscribed and generally used platforms like the Twitter, WhatsApp and Facebook. These platforms disseminate tailored negative narratives and damaging innuendoes to concerned group members on injustices against shared values, belief and help generate unprecedented awareness leading to widespread mobilization against rival groups or the state. No wonder the federal government hid under the deletion of President Muhammadu Buhari's tweet publicly considered genocidal against Igbo people of the Southeast to suspend the operation of twitter in Nigeria. The suspension or ban as the case might be explained why and how the second \#RevolutionNow protest scheduled for June 12, 2021 was aborted. Twitter spontaneously spreads information in manners that even television and radio stations do not and can never reach the people. In Nigeria where most citizens are aggrieved against the insensibilities of government, group members find social media platforms as veritable avenues for sharing bottled emotional grievances that touch the heart and generate public sympathy.

\section{Summary of Findings}

From the foregoing, the following findings are deductible:

1) That widespread internet penetration, broadband coverage, use of smart phones and other android devices have revolutionized telecommunication landscape in Nigeria;

2) That social media activism has provided opportunities for expression of grievances and demand for accountability from Nigerian government;

3) That social media platforms constitute veritable tools and avenues for awakening the consciousness and mobilization of group members;

4) That \#BringBackOurGirls, \#RevolutionNow and \#EndSars Protests in Nigeria were largely mobilized and implemented using the instrumentality of social media platforms;

5) That widespread use of unregulated social media is largely responsible for prevalence of sociopolitical protests against unabated injustices and government insensitivities in Nigeria.

\section{Concluding Remarks}

In the age of social media with multiple chat groups and virality of posts, people get easily angered by what they feel might affect or is affecting their relatives, friends and are against their shared interests and belief. Fanatics and promoters of the group, sectional and other cleavages use clichés and divisive languages to achieve set objectives. Nigerian citizens who were hitherto deprived of freedom of expression with muzzled press ventilate their anger and demand accountabil- 
ity through social media platforms, the opposition and even disgruntled politicians share uncommon views and facts about the government. Those areas where conventional media are banned from covering are covered by social media thereby granting users avenues of open criticisms against derailing governments and their agencies.

The \#BringBackOurGirls, \#RevolutionNow and \#EndSARS showed how Twitter, WhatsApp and some other social media platforms were deployed for coordinating activists' campaigns and oppositional discourses in Nigeria (Obia, 2020). The movements further demonstrated the power of social media in popularizing issues, facilitating the assembly of people and getting them to participate in fights against such issues. Hence, in Nigeria where democratic institutions are weak and captured by the state, citizens now rely on social media-enabled demonstrations, protests, campaigns, petitions, marches, and organizations to express their preferences and demand accountability from the governments. Many speak truth to power through social media handles over change or deterioration of political, social, and or economic situations (Lopes, 2014). Contemporary socio-political movements rely largely on social media to mobilize and gain public support by sharing views and opinions that are capable of generating public sympathy for their challenges. Clearly, social media have provided ample platforms for people to aggregate views, interests, organize and mobilize themselves against government policies and actions. Social media tools such as Facebook, Twitter, YouTube, email, text messaging, and photo sharing have enhanced social interactions, communications, and public participation in social movements.

\section{Conflicts of Interest}

The authors declare no conflicts of interest regarding the publication of this paper.

\section{References}

Allcott, H., \& Gentzkow, M. (2017). Social Media and Fake News in the 2016 Election. Journal of Economic Perspectives, 31, 211-236. https://doi.org/10.1257/jep.31.2.211

Aye, B. (2019, October 29). \#RevolutionNow: Fanning the Embers of Revolt in Nigeria. Review of African Political Economy. https://roape.net/2019/10/29/revolutionnow-fanning-the-embers-of-revolt-in-nigeria

Baruah, T. D. (2012). Effectiveness of Social Media as a Tool of Communication and Its Potential for Technology Enabled Connections: A Micro-Level Study. International Journal of Scientific and Research Publications, 2, 1-10. http://www.ijsrp.org/research_paper_may2012/ijsrp-may-2012-24.pdf

Buechler, S. M. (1995). New Social Movement Theories. The Sociological Quarterly, 36, 441-464. https://doi.org/10.1111/j.1533-8525.1995.tb00447.x

Conover, P. J. (1988). The Role of Social Groups in Political Thinking. British Journal of Political Science, 18, 51-76. https://doi.org/10.1017/S0007123400004956

Data Reportal (2021, February 11). Digital 2021: Nigeria.

https://datareportal.com/reports/digital-2021-nigeria 
Lopes, A. R. (2014). The Impact of Social Media on Social Movements: The New Opportunity and Mobilizing Structure. Journal of Political Science Research, 2-23.

https://www.creighton.edu/fileadmin/user/CCAS/departments/PoliticalScience/Journal _of_Political_Research_JPR_/2014_JSP_papers/Lopes_JPR.pdf

McAdam, D., McCarthy, J. D., \& Zald, M. N. (1988). Social Movements. In N. J. Smelser (Ed.), Handbook of Sociology (pp. 695-737). Sage Publications.

Miller, A. H., Gurin, P., Gurin, G., \& Malanchuk, O. (1981). Group Consciousness and Political Participation. American Journal of Political Science, 25, 494-511. https://doi.org/10.2307/2110816

Norris, P., Walgrave, S., \& van Aelst, P. (2005). Who Demonstrates? Anti-State Rebels, Conventional Participants, or Everyone? Comparative Politics, 37, 189-205. https://doi.org/10.2307/20072882

Obia, V. (2020). \#EndSARS, a Unique Twittersphere and Social Media Regulation in Nigeria. London School of Economics and Political Science.

https://blogs.lse.ac.uk/medialse/2020/11/11/endsars-a-unique-twittersphere-and-social -media-regulation-in-nigeria

Ojebode, A. (2018, October 10). How Bring Back Our Girls Went from Hashtag to Social Movement, While Rejecting Funding from Donors. Oxfamblogs.

https:/oxfamblogs.org/fp2p/how-bring-back-our-girls-went-from-hashtag-to-social-m ovement-while-rejecting-funding-from-donors

Phongpaichit, P. (1999). Theories of Social Movements and Their Relevance for Thailand. Social Movements in Thailand. A Position Paper for Project on Social Movements in Thailand, a Project Supported under the Thailand Research Fund's Methi Wichai Awuso Programme. http://pioneer.netserv.chula.ac.th/ ppasuk/theorysocmovt.doc

Sturken, M., \& Cartwright, L. (2018). Practices of Looking: An Introduction to Visual Culture. Oxford University Press.

Teh, P. L., Huah, L. P., \& Si, Y. W. (2014). The Intention to Share and Re-Shared among the Young Adults towards a Posting at Social Networking Sites. New Perspectives in Information Systems and Technologies, 1, 13-21.

https://doi.org/10.1007/978-3-319-05951-8_2

Torres, R. R., Gerhart, N., \& Negahban, A. (2018). Combating Fake News: An Investigation of Information Verification Bahaviours on Social Networking Sites. Proceedings of the 51st Hawaii International Conference on System Sciences, Waikoloa Village, 2-6 January 2018, 3976-3985. https://doi.org/10.24251/HICSS.2018.499

Ugobude, F. (2020, October 21). How Technology Is Playing a Crucial Role in the \#EndSARS Protests. OkayAfrica.

https://www.okayafrica.com/protest-in-nigeria-end-sars-technology

van Stekelenburg, J., \& Klandermans, B. (2009). Social Movement Theory: Past, Present and Prospects.

https://www.researchgate.net/publication/254828894_Social_movement_theory_Past_ present_and_prospect

Varrella, S. (2021). Leading Social Media Platforms in Nigeria 2020. Statista. https://www.statista.com/statistics/1176101/leading-social-media-platforms-nigeria 